Article

\title{
Cloud Cover Assessment for Operational Crop Monitoring Systems in Tropical Areas
}

\author{
Isaque Daniel Rocha Eberhardt ${ }^{1, *}+{ }^{\dagger}$, Bruno Schultz ${ }^{2,}{ }^{+}$, Rodrigo Rizzi ${ }^{3}$, Ieda Del'Arco Sanches ${ }^{2}$, \\ Antonio Roberto Formaggio ${ }^{2}$, Clement Atzberger ${ }^{4}$, Marcio Pupin Mello ${ }^{5}$, Markus Immitzer ${ }^{4}$, \\ Kleber Trabaquini ${ }^{6}$, William Foschiera ${ }^{2}$ and Alfredo José Barreto Luiz ${ }^{7}$ \\ 1 Universidade de Brasília, Campus Universitário Darcy Ribeiro, Pós-graduação em Transportes, \\ Anexo SG-12, $1^{\circ}$ andar, CEP 70910-900 Brasilia, Brazil \\ 2 Instituto Nacional de Pesquisas Espaciais (INPE), Divisão de Sensoriamento Remoto (DSR), \\ Avenida dos Astronautas 1.758, 12227-010 São José dos Campos, Brazil; schultz@dsr.inpe.br (B.S); \\ ieda@dsr.inpe.br (I.D.A.S); formag@dsr.inpe.br (A.R.F.); wfoschiera@dsr.inpe.br (W.F.) \\ 3 Universidade Federal de Pelotas-UFPel, Campus Universitário S/N, Caixa postal 354, \\ 96001-970 Pelotas-RS, Brazil; rodrigo.rizzi@ufpel.edu.br \\ 4 Institute of Surveying, Remote Sensing and Land Information (IVFL), University of Natural Resources and \\ Life Sciences, Vienna (BOKU), Peter Jordan Strasse 82, 1190 Vienna, Austria; \\ clement.atzberger@boku.ac.at (C.A.); markus.immitzer@boku.ac.at (M.I.) \\ 5 The Boeing Company, Boeing Research and Technology Brazil, 12247-016 São José dos Campos-SP, Brazil; \\ marcio.p.mello@boeing.com \\ 6 Agricultural Research and Rural Extension Company of Santa Catarina-Epagri. Santa Catarina State \\ Information Center on Environmental and Hydrometeorological Resource-CIRAM. Rod. Admar Gonzaga, \\ Itacorubi 1.347, Caixa Postal 502, 88034-901 Florianópolis-SC, Brazil; klebertrabaquini@epagri.sc.gov.br \\ 7 Embrapa Environment, Caixa Postal 69, 13820-000 Jaguariúna-SP, Brazil; alfredo.luiz@embrapa.br \\ * Correspondence: isaquedanielre@hotmail.com; Tel.: +55-61-9901-56568 \\ + These authors contributed equally to this work.
}

Academic Editors: Richard Gloaguen and Prasad S. Thenkabail

Received: 5 November 2015; Accepted: 1 March 2016; Published: 8 March 2016

\begin{abstract}
The potential of optical remote sensing data to identify, map and monitor croplands is well recognized. However, clouds strongly limit the usefulness of optical imagery for these applications. This paper aims at assessing cloud cover conditions over four states in the tropical and sub-tropical Center-South region of Brazil to guide the development of an appropriate agricultural monitoring system based on Landsat-like imagery. Cloudiness was assessed during overlapping four months periods to match the typical length of crop cycles in the study area. The percentage of clear sky occurrence was computed from the $1 \mathrm{~km}$ resolution MODIS Cloud Mask product (MOD35) considering 14 years of data between July 2000 and June 2014. Results showed high seasonality of cloud occurrence within the crop year with strong variations across the study area. The maximum seasonality was observed for the two states in the northern part of the study area (i.e., the ones closer to the Equator line), which also presented the lowest averaged values $(15 \%)$ of clear sky occurrence during the main (summer) cropping period (November to February). In these locations, optical data faces severe constraints for mapping summer crops. On the other hand, relatively favorable conditions were found in the southern part of the study region. In the South, clear sky values of around $45 \%$ were found and no significant clear sky seasonality was observed. Results underpin the challenges to implement an operational crop monitoring system based solely on optical remote sensing imagery in tropical and sub-tropical regions, in particular if short-cycle crops have to be monitored during the cloudy summer months. To cope with cloudiness issues, we recommend the use of new systems with higher repetition rates such as Sentinel-2. For local studies, Unmanned Aircraft Vehicles (UAVs) might be used to augment the observing capability. Multi-sensor approaches combining optical and microwave data can be another option. In cases where wall-to-wall maps are not mandatory, statistical sampling approaches might also be a suitable alternative for obtaining useful crop area information.
\end{abstract}


Keywords: clear sky coverage; agriculture monitoring; crop classification; MODIS

\section{Introduction}

Monitoring crop acreage and crop conditions is essential for several stakeholders, especially for those countries that produce large amounts of agricultural commodities such as Brazil, who plays an important role in the agricultural production worldwide [1]. Its Center-South region (with more than $800,000 \mathrm{~km}^{2}$ ) is a very traditional agricultural region, where approximately $45 \%$ of the Brazilian agriculture is concentrated [2]. During the crop season 2012/2013, summer crops such as soybean, maize and sugarcane occupied about 27, 16 and 9 million hectares (ha) in that region. Winter crops, such as wheat, barley and rye, occupied together about two million ha [2]. As cloudiness strongly impacts optical remote sensing imagery, its spatio-temporal distribution needs to be studied. Globally available cloud statistics such as from ISPCC [3] are too coarse for providing the necessary information at sub-regional scale.

Official crop acreage estimates in Brazil are currently obtained using quite subjective techniques such as questionnaires distributed to the actors of the productive chain [4]. Similar approaches to estimate crop acreages are used in many other countries as well [5]. Although low-cost, the subjectivity of this approach makes the data difficult to be used following statistical/mathematical methods, for example to evaluate the quality (error) of the estimates [6]. For example, the United Nation's Food and Agricultural Organization (FAO), the United States Department of Agriculture (USDA) and the European Union (EU), publish crop estimates obtained from national countries' statistical services and generally do not include measures of uncertainties [7-10]. Another problem relates to the timing of the provided information. The majority of the statistical bureaus publish their values near the end of the crop season [7]. Sometimes additional delays are observed before the statistics are released.

To address these problems, the G20 group (representatives of the 20 major economies) established in 2011 a global initiative to improve the monitoring of major crops using Earth Observations (EO) systems, called GEOGLAM [11,12]. Within GEOGLAM, the use of optical satellite imagery is promoted as it has demonstrated great potential to obtain crop acreage information at regional level, especially using Landsat/Sentinel2-like images [13-18]. Indeed, many studies have demonstrated that optical remote sensing imagery may be used to accurately identify crops such as soybean [19-21], sugarcane $[22,23]$ and maize $[20,24]$, as well as many other crops $[21,25,26]$. However, remote sensing is not yet widely used for near-real-time monitoring at regional and national scales as the analysis of EO data still presents big challenges [27]. This is even more true when using EO data to assess crop yield [12,28].

To use remote sensing imagery for operational assessment of crop acreage it has to be considered that satellites have to balance coverage, spectral, spatial and temporal resolution [29]. Usually, when the spatial resolution is suitable to identify and to map crops, only a few observations along the vegetative crop cycle are available as the temporal resolution is relatively low [30,31]. For example, Landsat only offers seven potential acquisitions (with 16-day revisit time), to identify a typical annual summer crop with a cycle of around four months [30,31]. This number does not yet consider that the spectral response at the start and end of the crop cycle is usually not sufficient to support the crop differentiation. During early stages of development, the spectral response is strongly affected by soil background effects, and in the final stages of crops (before harvest) the major response comes from straw or dry crop. Hence, the useful time period is often shorter than the theoretical four months summer crops period [32]. More importantly, to map crops in tropical and subtropical regions using optical sensors, additional problems arise due to the often-high cloud coverage, which further reduces the number of available (and useful) observations [33,34].

To overcome the cloud cover issue, probabilistic sampling methods have been developed for crop acreage estimation, minimizing the need of wall-to-wall mapping [35-39]. In such approaches, random 
sampling within the cloud-free portions of the images is used for classification. Obviously, new sensors such as the European Sentinel-2 try to shorten the temporal revisit frequency while keeping a high spatial and spectral resolution.

To quantify and understand the occurrence of cloud cover, a large number of studies were conducted [40-46]. Few of them, however, have identified the impact of cloud cover in a system of crop acreage estimation using remote sensing images. To develop a consistent, systematic and continuous acreage estimation system based on optical remote sensing data it is necessary to assess suitable observation conditions [12,30,40]. In this context, the project Monitoring Brazilian Agriculture by Remote Sensing (MOBARS) was established. In the project, researchers from the Brazilian National Institute for Space Research (INPE), the Brazilian Agricultural Research Corporation (EMBRAPA) and the University of Natural Resources and Life Sciences, Vienna (BOKU) worked together to develop and implement a satellite-based agricultural monitoring system for Brazil. The ultimate aim of the project is to implement a bimonthly EO-based operational crop monitoring system, complementing the official agricultural statistics that are monthly published in Brazil. To estimate acreage in near real-time, a process was designed based on Landsat imagery and random sampling techniques using mesoregions as sampling strata for the sampling frame. The mesoregions are defined by the Brazilian Institute of Geography and Statistics (IBGE) as subdivisions of the States that group together municipalities that are geographically close and share come common characteristics [47].

This paper aims to assess the spatial and temporal variability of cloud cover conditions in tropical areas of Brazil and its consequences on the implementation of a (preferably bimonthly) operational crop monitoring system based on Landsat-like optical EO data. The assessment was performed over 14 crop seasons (2000 to 2014) in four states of Brazil, representative for Brazil in terms of agricultural production.

\section{Methodology}

\subsection{Study Site}

The study area covers four Brazilian states: São Paulo (SP), Paraná (PR), Santa Catarina (SC), and Rio Grande do Sul (RS). The four states are located between latitudes South $19^{\circ} 42^{\prime}$ and $33^{\circ} 48^{\prime}$ and longitudes West $44^{\circ}$ and $57^{\circ} 41^{\prime}$ and contain 38 mesoregions (Figure 1).

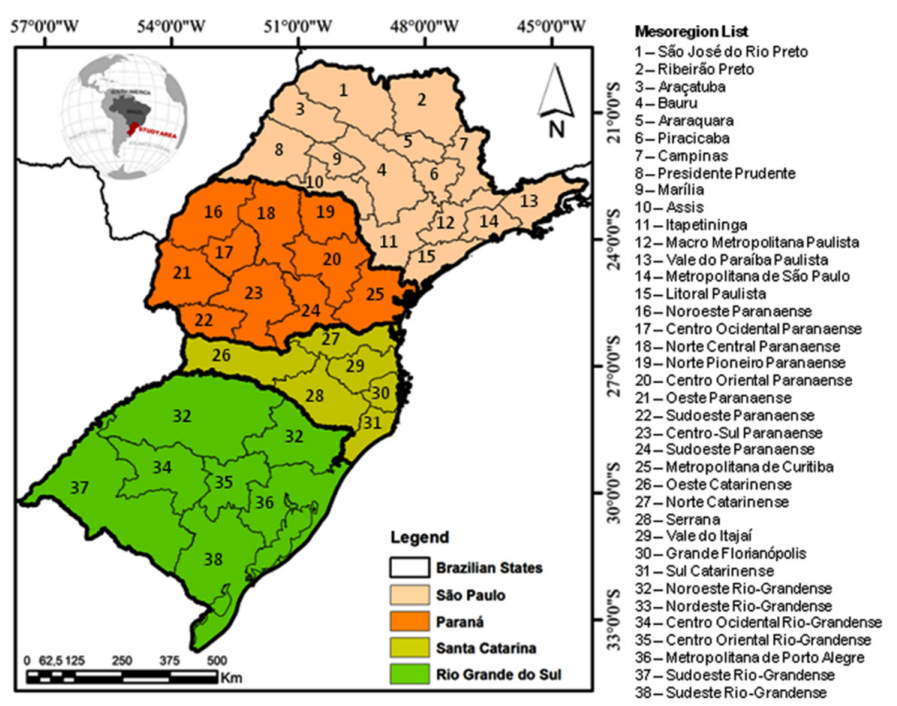

Figure 1. The study area in Brazil encompasses the following states: São Paulo (SP), Paraná (PR), Santa Catarina (SC) and Rio Grande do Sul (RS). These four states are divided in 38 mesoregions, defined by IBGE [47]. 
In Brazil, the crop year runs from July to June. Depending on the region, one to three crop cycles per year are possible within the same agricultural field. In the study area, short-cycle crops can last up to 120 days, and can be sowed anytime during the crop year, depending on water availability. Long-cycle crops, such as sugarcane, can last between 1 to 1.5 years and require a dry season to reach physiological maturity $[48,49]$.

The spatially uneven distribution of short-cycle crops (winter and summer crops) and long-cycle crops (sugarcane) is depicted in Figure 2. Hence, to characterize the potential impact of cloud cover in a satellite-based crop monitoring system, its sub-regional distribution and temporal variability have to be assessed. To cover observation requirements of short- and long-cycle crops, the study considered temporal windows of four months (Figure 3).

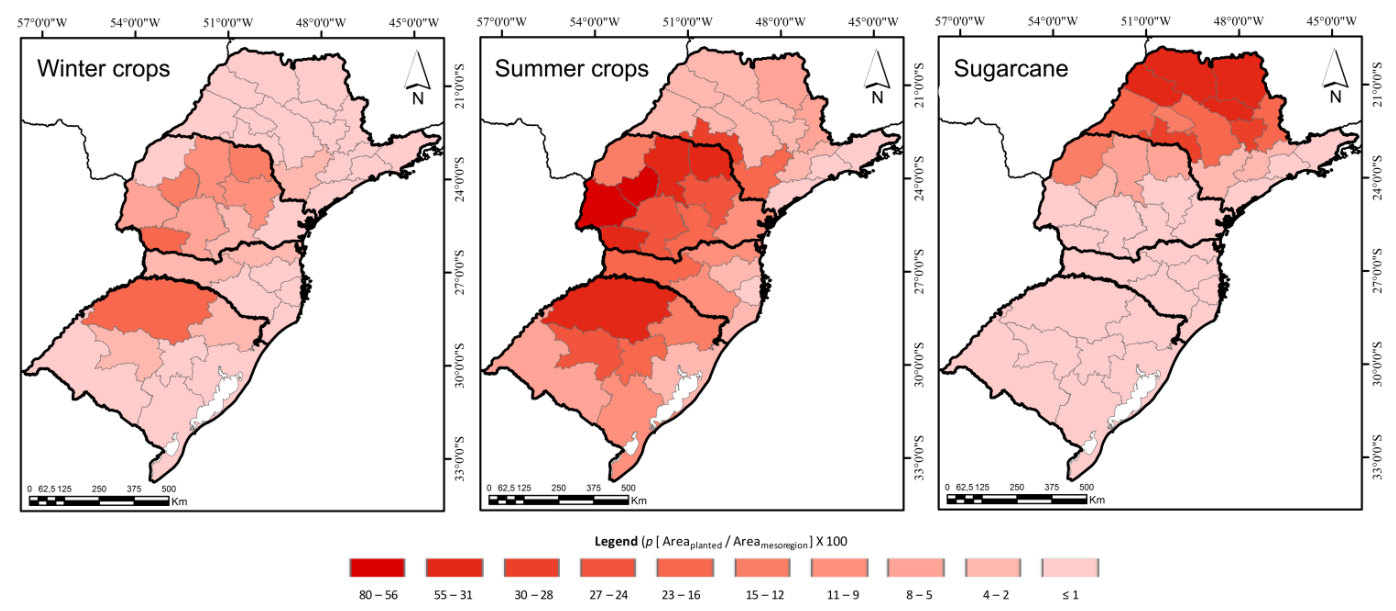

Figure 2. Spatial distribution of various crops over the study area. Acreage estimates are from IBGE for the crop season 2011/2012 (the last available at mesoregion scale). Winter crops include wheat, oats, barley and triticale, whereas summer crops considered soybean and maize.

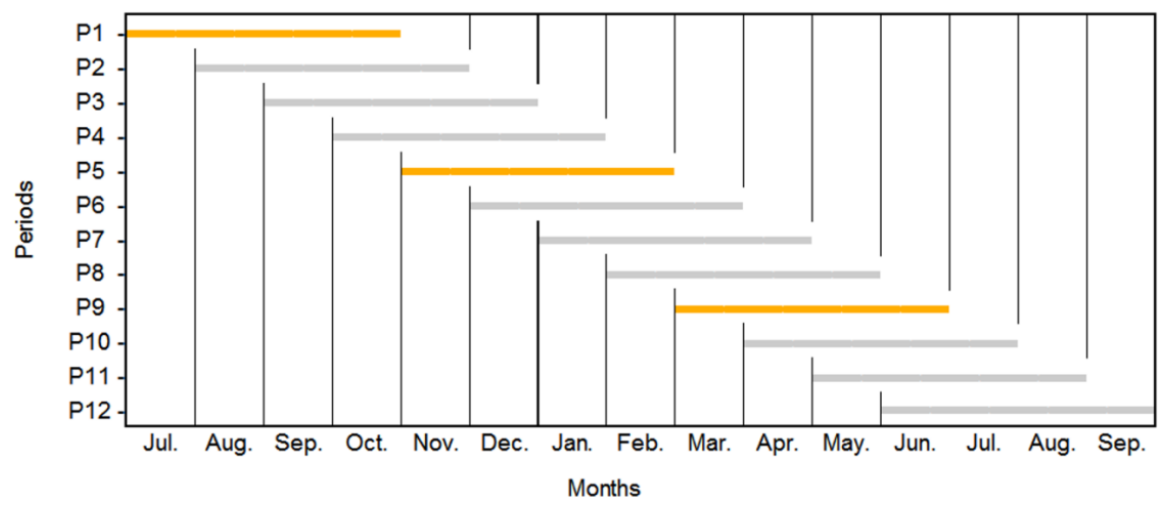

Figure 3. Analyzed crop periods; each horizontal bar represents a four months period corresponding to the average crop cycle length of main crops. In each temporal window, clear sky statistics are calculated. The brown bars are key periods for which additional Kolmogorov-Smirnov tests were run: P1 (1 July and 31 October), P5 (1 November to 28 February) and P9 (1 March to 30 June).

\subsection{MODIS Cloud Mask Product}

To generate seasonal cloud statistics for the study area, we analyzed the MODIS Cloud Mask product (version 5) from Terra satellite. The MODIS Cloud Mask is a L2 product from Earth Observation System (EOS) processing program. The data set provides a good overview about the clear sky conditions over large regions with short lag time and offers daily coverage since 2000 [42,43]. We have chosen this imagery because of the temporal proximity to the Landsat/Sentinel-2 acquisition times 
(Terra's equatorial crossing is approximately $30 \mathrm{~min}$ after Landsat). Existing diurnal variations in cloud cover have therefore been neglected. Landsat has been chosen as a reference because it is widely used in agricultural monitoring studies of the study region $[19,21-23,34,50]$.

The underlying cloud detection algorithm of MOD35 uses 22 out of the 36 MODIS wavebands to define cloud presence at pixel level [42,43]. The resulting mask is delivered at $1 \mathrm{~km}$ spatial resolution. Two files are used to compose a cloud mask image: one file containing the values of cloud cover (MOD35) and another file containing the geolocation fields (MOD03) [42]. The MOD35 product is composed of five bytes where bits 1 and 2 of byte 0 show the value of cloud cover for each MODIS pixel. It has four labels to represent distinct cloud cover conditions: cloudy ( $<60 \%$ confidence interval), uncertain clear (60\% to $95 \%$ ), probably clear (>95\% to $99 \%$ ) and confident clear (>99\%) [41].

\subsection{Clear Sky Statistics}

The images of the study area were extracted from the HDF files following the GEOTIFF format by the MODIS Reprojection Tool Swath [51]. We analyzed all images from 1 July 2000 to 30 June 2014 (14 crop years). For the processing, we made use of the $\mathrm{R}$ software version 3.1.2 [52] and the modiscloud [53] and raster [54] packages. The two packages allow to manipulate any kind of raster data, respectively, to analyze MODIS cloud products.

The four original classes of the MODIS cloud mask product were regrouped into two broad classes [41-43]:

- clear sky (confident clear), and,

- cloudy (probably clear + uncertain clear + cloudy).

To derive clear sky statistics, the 14 years of MOD35 daily images were aggregated into 12 temporally overlapping periods of four months as depicted in Figure 3.

The three main periods highlighted in Figure 3 represent the most widely used cropping periods in the Brazilian agriculture. The majority of the all crops are cultivated during these three four months periods. These periods correspond to the Brazilian winter, summer and double-crop growing seasons, respectively. However, for the development of a crop monitoring system, it is worthwhile to check all twelve periods, as there may be some crops cultivated during the entire year, for example within irrigated systems. Sugarcane is even more particular as it is a long-cycle crop (1-1.5 years). Therefore, all twelve periods were considered important to evaluate the crop conditions in the study area.

For each four months period (P1 to P12), the percentage of clear sky class was calculated at pixel level based on the total number of clear observations per year. From the 14 individual years, the average was computed and 12 clear sky cover maps (regarding P1 to P12) with a spatial resolution of $1 \mathrm{~km}$ were derived.

To characterize the clear sky seasonality per mesoregion, the cumulative relative frequency (CRF) was derived for each mesoregion from the twelve clear sky cover maps. To check for significant seasonal differences among CRFs by each mesoregion, the Kolmogorov-Smirnov (KS) test [55], with $5 \%$ significance level, was used, where the H0 hypothesis stated that "there is no seasonality between periods in each mesoregions throughout the year in the study area". The test was applied for the three key periods: P1, P5 and P9 (Figure 3). The three periods were compared in pairs: P1 vs. P5 (test A), P1 vs. P9 (test B), and P5 vs. P9 (test C). Since the data did not follow a Gaussian distribution we did not use parametric tests.

\section{Results}

The clear sky cover maps in Figure 4 show clear spatial and temporal patterns within each of the 12 periods. For the time span 2000-2014 and all 12 periods, relatively high cloud coverage was found along the coast in a strip of about $100 \mathrm{~km}$ ranging from south-São Paulo (SP) through Paraná (PR) until Santa Catarina (SC). Along the year, there was an alternation of cloudiness between São Paulo (SP) and Rio Grande do Sul (RS). SP state showed high cloud coverage from September to March (spring 
to summer; summer crops), whereas RS tended to present high cloud coverage from late March to September, which corresponds to autumn and winter in the South hemisphere. West corners of PR and SC, on the other hand, showed relatively low seasonality with consistent moderate clear sky coverage (average 45\%) throughout the whole year (Figure 4).
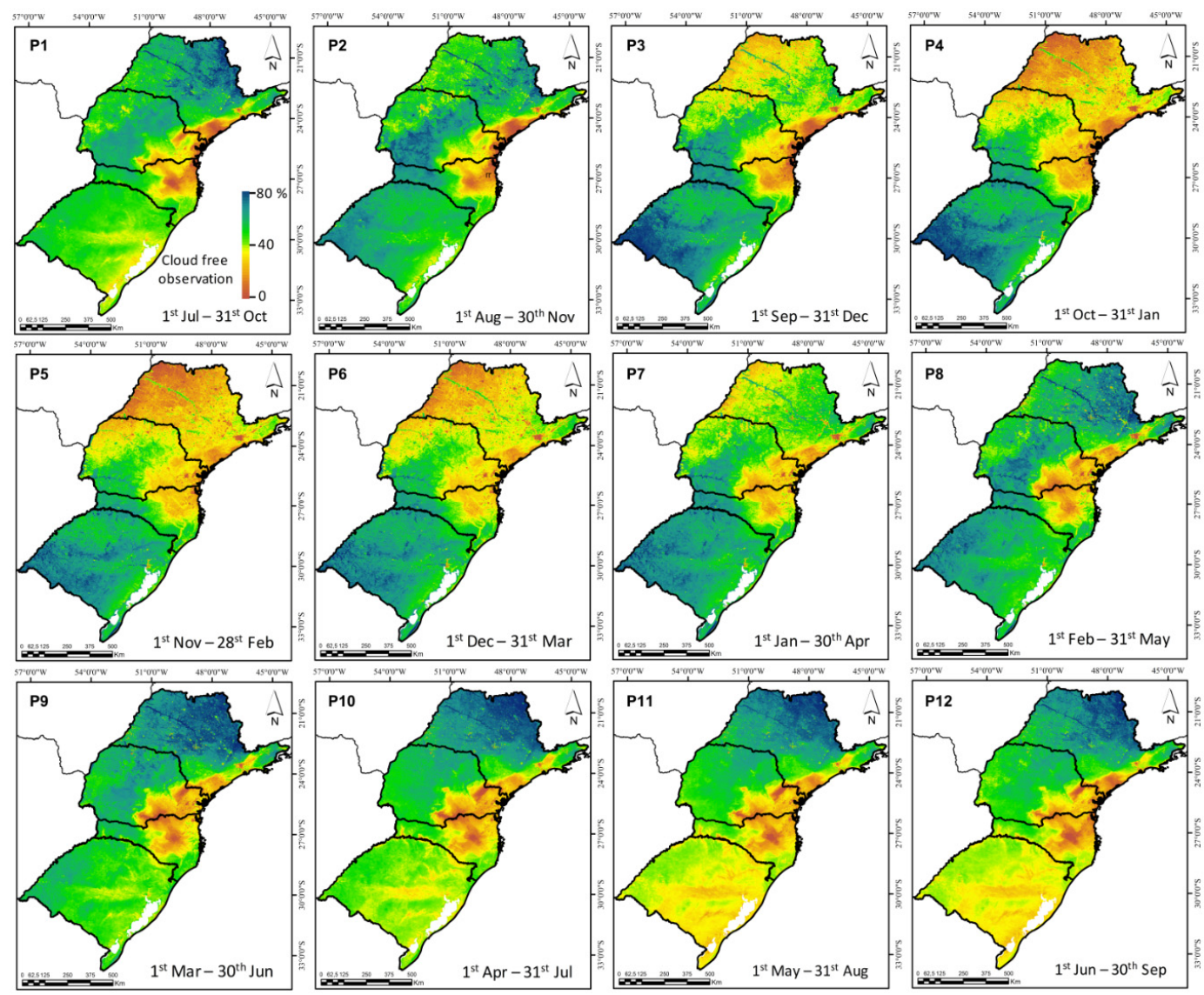

Figure 4. Average clear sky cover conditions for the study area. Each map represents four monthly averaged percentage of clear sky cover observation, computed based on the MOD35 product, considering the period between 1 July 2000 and 1 June 2014.

We observed significant differences in clear sky cover and seasonality between the northern and southern parts of the study area. Indeed, the North-South differences become more evident by comparing the São José do Rio Preto mesoregion (northern corner of SP, $20^{\circ} 30^{\prime}$ latitude) with the Sudeste Rio-Grandense mesoregion (southern corner of RS, $31^{\circ} 30^{\prime}$ latitude). Figure 5 shows the CRF of the 12 periods for the two mesoregions. In São José do Rio Preto, the monitoring of summer crops is complicated as the cropping period coincides with periods of high cloudiness. On other hand, Sudeste Rio-Grandense reveals no difference in clear sky conditions for all 12 four months periods.

According to the KS test, significant differences of CRF between the key periods were found for some mesoregions (Figure 6). For test A (P1 vs. P5), the majority (68\%) of the mesoregions (mainly in SP, $\mathrm{PR}$, and SC states) presented significant differences between CRF. For test B (P1 vs. P9), no significant differences were observed, except for two mesoregions (Marília-SP and Noroeste Paranaense-PR). For test C (P5 vs. P9) 63\% of the mesoregions presented significant differences between CRF. 


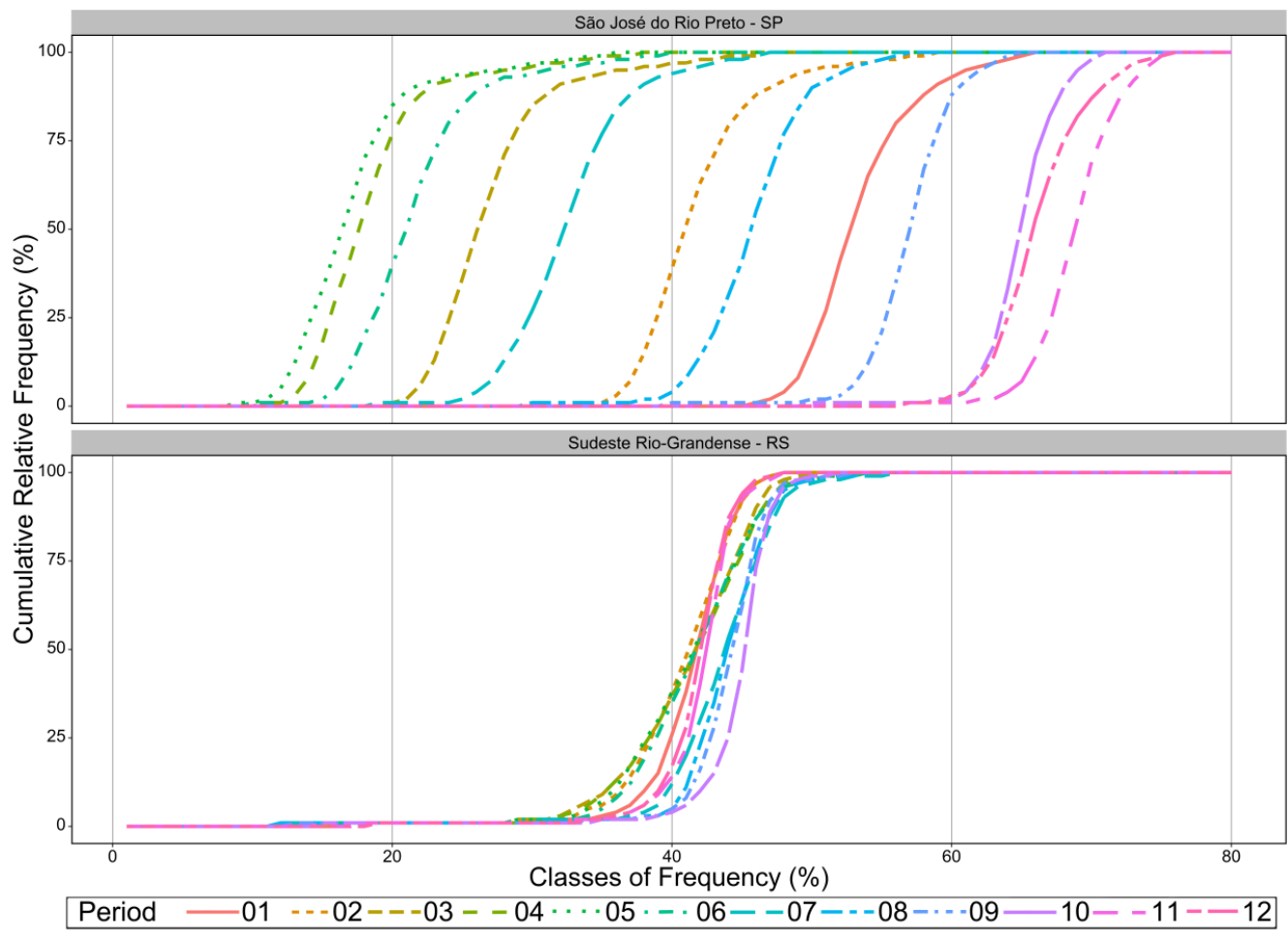

Figure 5. Cumulative frequency of clear sky coverage for two mesoregions of the study area: (top) the northern mesoregion São José do Rio Preto (SP), with high seasonality; and (bottom) the southern mesoregion Sudeste Rio-Grandense (RS) with low seasonality. Each curve represents the cumulative frequency of averaged clear sky cover in four months periods as indicated in Figure 2.

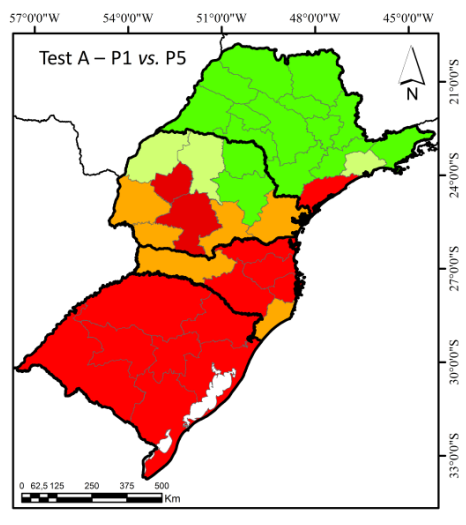

$\square$ Extremely significant:
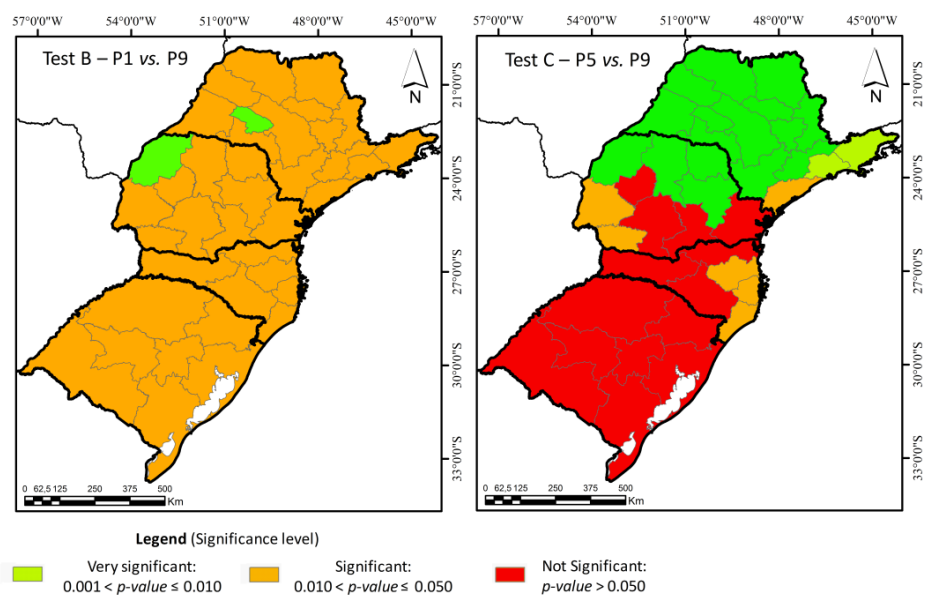

Figure 6. Kolmogorov-Smirnov test of differences of the main crop periods. The test is used to evaluate the clear sky percentage occurrence seasonality of the mesoregions in the study area. Test $A=1$ July to 31 October (P1) against 1 November to 28 February (P5). Test B = 1 July to 31 October (P1) against 1 March to 30 June (P9). Test C $=1$ November to 28 February (P5) against 1 March to 30 June (P9). A KS value of 0.152 is the critical value for Kolmogorov-Smirnov size of sample $n=81$ (between 0 and $80 \%$ of clear sky coverage).

The KS test confirmed the evidence about seasonality of clear sky occurrence in the northern part of the study region, mainly in SP (Figure 6). In this region, we identified statistically significant differences between P1 and P5 (in green). This confirms the potential difficulties when monitoring crops during the period P5 (summer crop season, when major crops in the region are soybean and 
maize), since the P1 is the dry season in the study region. For the Center-South of the study region, on the other hand, there were no statistical differences between the major crop monitoring periods (e.g., all mesoregions appear red in Figure 6). Overall, it is evident that a mapping system for the entire area will be more viable for sugarcane than for summer and winter crops.

\section{Discussion}

Crop monitoring based on optical EO data in tropical areas is a challenge [12,56,57]. In our study area in Center-South of Brazil, the crop types are unevenly distributed over the area. Each crop has its own calendar with different growing seasons following distinctly different phenological developments. As field sizes are relatively small, observation conditions (e.g., cloudiness) have to be characterized at the spatial resolution of Landsat/Sentinel-2 type of imagery. The statistical characterization and subsequent mapping of cloudiness as an important external constraint helps designing a suitable monitoring system. In this respect, we analyzed the potential of the MODIS cloud mask product (MOD35) to derive cloud statistics. The developed and employed method used multiple years to obtain more useful, consistent and plausible results (e.g., with respect to cloudiness) at relatively fine spatial scale $(1 \mathrm{~km})$ compared to other products such as the ISPCC cloud data maps with a spatial resolution of $3.5^{\circ}[3]$.

Based on our analysis, we found large differences of cloudiness in terms of spatial and temporal patterns. This variability has effects on the ability to monitor crops in the study area. Table 1 summarizes the interference of cloudiness with crop monitoring needs for the four analyzed states and the three main crop categories.

Table 1. Interference of cloudiness with crop monitoring needs for the four states of the study area: (+) low interference, (o) light interference, (-) strong interference. If a particular crop is not present in a given state (n.a.) not applicable is reported

\begin{tabular}{ccccc}
\hline & & \multicolumn{3}{c}{ State } \\
& São Paulo (SP) & Paraná (PR) & Santa Catarina (SC) & Rio Grande do Sul \\
\hline Winter crops & + & + & + & + \\
Summer crops & - & - & o & + \\
Sugarcane & $\mathbf{0}$ & n.a. & n.a. & n.a. \\
\hline
\end{tabular}

For summer crops in São Paulo (SP) State (mainly soybean and maize) (Figure 2), the crop development period falls within a period of high cloud coverage (Figure 4). Since there is such a low probability to obtain cloud-free images, mapping of summer crops (e.g., between September and March) is complicated in SP. Regarding sugarcane, an optical remote sensing operational monitoring system seems to be feasible in SP, as the crop cycle lasts at least one year and the period of harvesting falls into the dry season with generally low cloudiness. This has been confirmed in the literature. Rudorff et al. [23], for instance, showed the possibility of mapping sugarcane with Landsat data in SP state.

In Paraná (PR) State, summer crops are concentrated in the central and western part of the state, which contains more than five million hectares planted with soybeans and maize, nearly $90 \%$ of the total cropped area [58] (Figure 2). In this state, some of the mesoregions show high seasonality of clear sky conditions. The cloud cover is varying from 40 up to $70 \%$. Therefore, parts of these areas are so persistently occluded by clouds that it is not possible to generate consistent maps based on optical remote sensing images $[30,33,40,41]$. The problematic of mapping summer crops based on optical images is in line with findings of Sugawara et al. [34], who concluded that the temporal resolution of Landsat is not sufficient to perform a systematic mapping of soybean.

The main growing areas of soybean and maize of Santa Catarina (SC) State are in the Oeste Catarinense mesoregion, in the western part of the state (Figure 2). For this region, the percentage of clear sky cover is less seasonal than in SP and PR State with values ranging between $50 \%$ and 
$60 \%$ (Figure 4). This should permit an acceptable coverage with high resolution optical EO data, and making it feasible to map summer crops.

Among the four states of the study area, the state Rio Grande do Sul (RS) showed the lowest seasonality of clear sky conditions (Figure 4). Most of the soybean and maize in this state are concentrated in the Noroeste Rio-Grandense mesoregion (Figure 2) [58]. For this mesoregion, the clear sky coverage percentage observed was around $60 \%$ for all twelve four months periods (Figure 4). This indicates favorable opportunities for crop monitoring based on optical EO data.

For winter crops (wheat, barley, rye, and triticale), the major producing regions are concentrated in the states of PR and RS (Figure 2), more or less in the same regions where soybean and maize are cultivated during the summer. Monitoring winter crops in the study area is more suitable, when compared to summer crops, as the crop development period coincides with low cloud coverage.

Figure 7 summarizes the clear sky conditions of main crops in the study area together with their corresponding crop calendars. Sugarcane, which requires a dry season to reach maturity, is predominant in SP and north of PR (Figure 2), where low rainfalls coincide with cloud free conditions, facilitating the sugarcane monitoring with remote sensing data. Indeed, the sugarcane harvesting period in that region usually lasts from late-March to early-December (8-months), which increases the probability to acquire cloud free imagery. Figures 2 and 4 also show that SP and the northern part of PR tend to present low cloud coverage for the mentioned period. Thus, mapping sugarcane using Landsat-like imagery is suitable in these regions as demonstrated in several studies [22,23,50]. Schultz et al. [21] classified four crop types (sugarcane, soybean, peanut, cassava) based on bi-temporal Landsat 8 data and achieved acceptable accuracies. However, they discussed that a better temporal resolution would be needed to better distinguish spectrally similar crops (e.g., peanut and cassava).

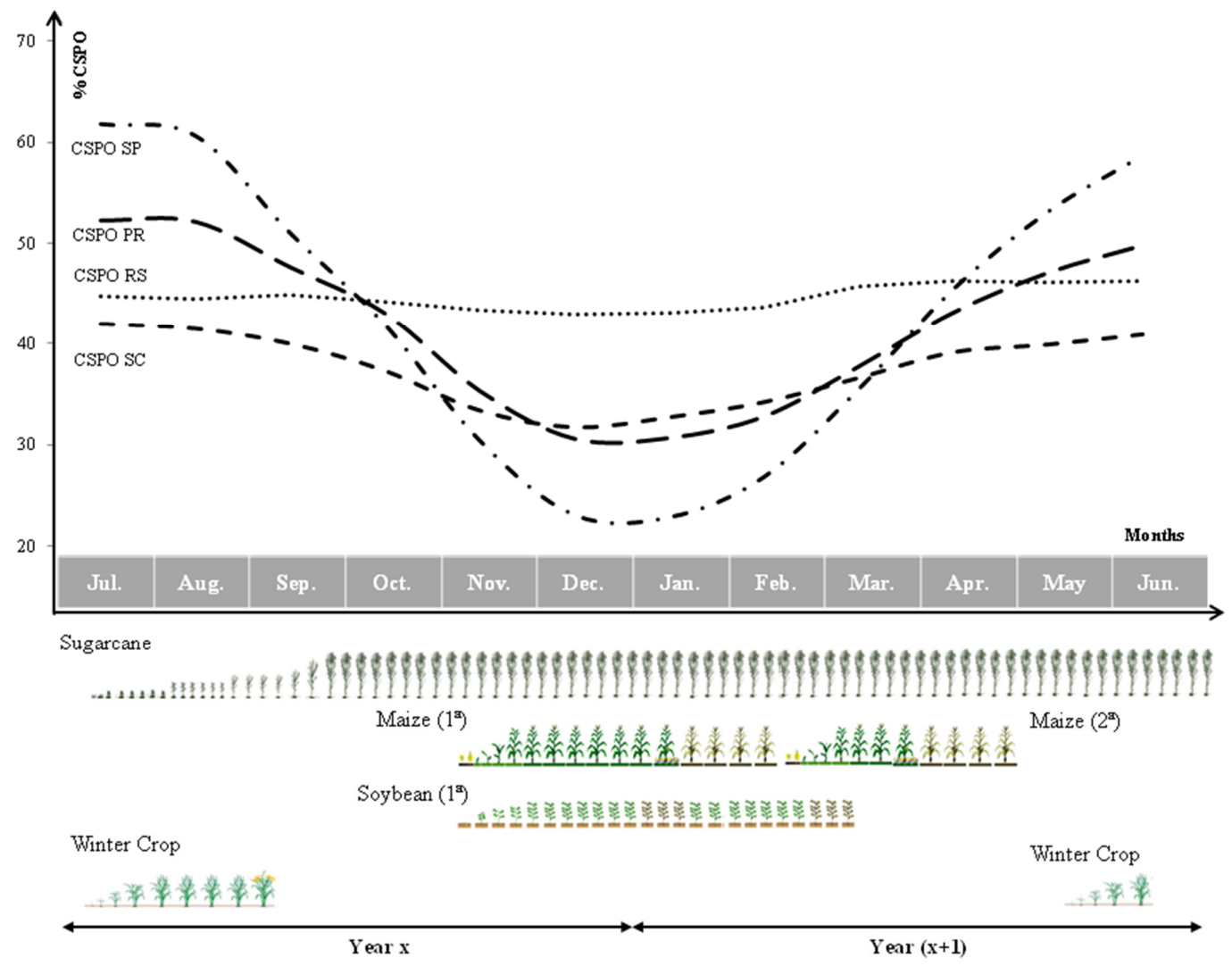

Figure 7. State-wise averages (black lines) of clear sky percentage occurrence (CSPO) calculated over 14 growing seasons (2000/2001 to 2013/2014). In the bottom part the development cycles of the major crops in the study area are shown. 
Given the profiles shown in Figure 7, the most problematic period for optical EO-based mapping is between December and January (P5) when clear sky coverage tended to be below $50 \%$. As a consequence, the monitoring of (first season) soybean and maize using EO data is very challenging (Figure 6). This is further reinforced by the fact that some of the planted crops have short cycles requiring cloud-free observations within short time windows. This problem is most evident in the mesoregions of SP, which are closer to the Equator line.

To monitor sugarcane, the probability of obtaining cloud-free images is high mainly from October to May. This guarantees a high suitability of a program to map and monitor the crop [23], as well as to perform statistical samplings [59]. For winter crops, cloudiness is generally lower, increasing the chance to obtain cloud-free images for an operational monitoring system. In contrast, regarding the summer crops, the high percentages of cloud cover during the summer makes the implementation of a mapping and monitoring system based on optical imagery for the study area challenging. Indeed, observing summer crops with optical EO becomes even more difficulty when crop masks have to be updated (in near-real time) over the crop cycle (e.g., every two months).

High cloud coverage observed for the summer period may jeopardize crop-monitoring systems based on optical remote sensing imagery in tropical areas. The low frequency of clear sky conditions certainly prevents the establishment of a near-real time monitoring system (e.g., mapping every two months). On the other hand, winter crops and long-cycle crops (e.g., sugarcane) are less affected by cloudiness as crop development falls within a period of low cloudiness. This was also confirmed through the mesoregion-based analyses (Figures 5 and 6). The crop calendar combined with cloud cover conditions revealed that long-cycle crops, such as sugarcane, are very suitable to be monitored using Landsat-like imagery. Sugarcane is, in fact, the main crop planted in SP state (around 5.5 million ha in 2015). Suitable conditions were also found for winter crops (wheat, barley, rye, and triticale) whereas the monitoring of soybean and maize in tropical areas may be strongly impacted by cloudiness, if the development period concurs with periods of high cloudiness.

Several studies $[20-23,50,60]$ have reinforced the use of multi-temporal imagery to map crops in Brazil. Notwithstanding, under the conditions of the study area, it is challenging to develop a large area monitoring system based on optical EO data. A suitable monitoring system has to take into account several aspects, such as the clear sky condition, crop dynamics and phenologies, crop management and availability of satellite images with adequate resolutions. In this respect, the recently launched Sentinel-2 and CBERS-4 satellites will bring benefits, but not completely solve the problems. Sensors with daily revisit frequency such as MODIS and PROBA-V are often incompatible with the environmental setting of the agricultural landscape due to the coarse spatial resolution compared to the field size [61,62]. Techniques which combine different sensors, platforms and wavelength ranges could be a solution [63]. A combination of Landsat/Sentinel-2 imagery with sensors on board of Unmanned Aircraft Vehicles (UAVs) is, for example, probably suitable.

A partial short-term solution to the issue of unsuitable observation conditions would be to use mosaicking and filtering techniques that combine parts of images without cloud cover [64]. Alternatively, sampling techniques [37-39] may be used to estimate crop acreage over large areas based on subsets of pixels or even small areas. In fact, even under the worst conditions observed within the study area, there was still a $17 \%$ percent of probability to find cloud free pixels. Therefore, even under the worst conditions, it would probably still be possible to estimate crop acreage using sampling techniques which are already in use $[35,59,65]$. In addition, the integration of active sensors into the monitoring system could be an option. Several studies showed the potential of different active satellite sensors for crop monitoring [66-68].

\section{Conclusions}

A statistical approach combining multiple years of the MOD05 Cloud Mask product was used to analyze cloud conditions in a study area in Brazil covering four states-São Paulo (SP), Paraná (PR), 
Santa Catarina (SC) and Rio Grande do Sul (RS). The proposed method is easy to implement and delivers results very fast also for large areas. A copy of the code can be made available on request.

Using the cloudiness information of the MOD05 product, we found that the implementation of an operational crop monitoring system based on optical imagery in tropical areas is possible, but challenging. Whereas winter crops and long-cycle crops (e.g., sugarcane) present favorable observation conditions due to the high probability to obtain could free images during the crop developing phase, mapping and monitoring summer crops showed to be an issue, as the growing period of the crops coincides with the rainy period.

The cloud conditions observed over the study area were not randomly distributed, neither in time nor in space. We found a significant contrast between regions further north (closer to the Equator line), where seasonality is large, compared to regions further south, where almost no seasonality in cloudiness was observed. The worst cloud cover conditions were observed in the period between November and February (rainy season in the region), especially in SP and PR. These two states also presented high seasonality of cloud coverage, with best conditions occurring between June and September (i.e., the winter). Low seasonality has been observed for SC and RS, where cloud conditions tended to be constant along the year, with percentages below $65 \%$ for the winter crop development period.

The spatial and temporal analysis of cloudiness highlighted the difficulties in establishing a crop monitoring system based on Landsat-like satellite imagery with revisit cycles of 16 days. Comparing the cumulative relative frequency of clear sky occurrence for each mesoregion throughout the year, we found statistical significant differences mainly for mesoregions belonging to the SP and PR States. At the same time, crop management also follows strong regional pattern. Together this implies that a large scale crop observation system solely based on optical satellite data would probably not be capable to map the entire region and all crops equally well. In our particular study area, the prevailing clear sky conditions probably require to adopt alternative methods if a bi-monthly (within season) crop mapping and monitoring system is to be established. Multi-sensor approaches using data from different EO systems, including new active and passive remote sensing data as well as Unmanned Aircraft Vehicles (UAVs), could be on option. We therefore recommend to further developing techniques that combine different sensors, platforms and wavelength ranges. Additionally, the combination of remote sensing methods with statistical sampling approaches should be investigated.

Acknowledgments: We thank the Brazilian Research Council CAPES (Coordenação de Aperfeiçoamento de Pessoal de Nivel Superior-402597/2012-5, 33010013005P0) for financial support. This research has been conducted under a cooperative project between Brazil's National Institute for Space Research (INPE) and the University of Natural Resources and Life Sciences (BOKU), Vienna, Austria.

Author Contributions: All authors conceived and designed the study; Isaque Daniel Rocha Eberhardt, Marcio Pupin Mello and Rodrigo Rizzi performed the data processing. Isaque Daniel Rocha Eberhardt analyzed results. Isaque Daniel Rocha Eberhardt, Rodrigo Rizzi, Ieda Del'Arco Sanches, Bruno Schultz, Clement Atzberger and Antonio Roberto Formaggio wrote the paper. Kleber Trabaquini, Marcio Pupin Mello, Markus Immitzer, William Foschiera and Alfredo José Barreto Luiz revised the paper.

Conflicts of Interest: The authors declare no conflict of interest.

\section{References}

1. Hermelingmeier, C. The competitive firm and the role of information about uncertain factor prices. Econ. Model. 2010, 27, 547-552. [CrossRef]

2. The Brazilian Institute of Geography and Statistics (IBGE). LSPA-Levantamento sistemático da produção agrícola; IBGE: Rio de Janeiro, Brazil, 2013.

3. ISCCP: INT ISCCP D2 Monthly Means and Climatology. Available online: http://isccp.giss.nasa.gov/ products/browsed2.html (accessed on 22 February 2016).

4. Pino, F.A. Estimação subjetiva de safras agrícolas. Inf. Econ. 2001, 31, 55-58.

5. Food and Agriculture Organization of the United Nations-Statistics Division. Available online: http://faostat3. fao.org/browse/Q/QC/E (accessed on 10 September 2015). 
6. Pino, F.A. Estatísticas agrícolas para o século XXI. Agric. São Paulo 1999, 46, 71-105.

7. Alexandratos, N.; Bruinsma, J. World Agriculture towards 2030/2050: The 2012 Revision; ESA Working Paper No. 12-03; FAO: Rome, Italy, 2012.

8. USDA Office of the Chief Economist-How the WASDE is Prepared. Available online: http://www.usda. gov/oce/commodity/wasde/prepared.htm (accessed on 10 January 2014).

9. EUROSTAT Agriculture-Statistics Illustrated. Available online: http://ec.europa.eu/eurostat/web/ agriculture/statistics-illustrated (accessed on 8 February 2016).

10. Vogel, F.A.; Bange, G.A. Understanding USDA Crop Forecasts; US Department of Agriculture: Washington, DC, USA, 1999.

11. GEOGLAM. Gloabal Argircultural Monitoring: Crop Monitor. Available online: http://www.geoglamcrop-monitor.org/ (accessed on 17 September 2015).

12. Whitcraft, A.K.; Becker-Reshef, I.; Justice, C.O. A framework for defining spatially explicit earth observation requirements for a global agricultural monitoring initiative (GEOGLAM). Remote Sens. 2015, 7, 1461-1481. [CrossRef]

13. Immitzer, M.; Vuolo, F.; Atzberger, C. First experience with sentinel-2 data for crop and tree species classifications in Central Europe. Remote Sens. 2016, 8, 166. [CrossRef]

14. Rudorff, B.F.T.; Adami, M.; Aguiar, D.A.; Moreira, M.A.; Mello, M.P.; Fabiani, L.; Amaral, D.F.; Pires, B.M. The soy moratorium in the Amazon biome monitored by remote sensing images. Remote Sens. 2011, 3, 185-202. [CrossRef]

15. Watts, J.D.; Lawrence, R.L.; Miller, P.R.; Montagne, C. Monitoring of cropland practices for carbon sequestration purposes in north central Montana by Landsat remote sensing. Remote Sens. Environ. 2009, 113, 1843-1852.

16. Congalton, R.G.; Balogh, M.; Bell, C.; Green, K.; Milliken, J.A.; Ottman, R. Mapping and monitoring agricultural crops and other land cover in the lower Colorado River Basin. Photogramm. Eng. Remote Sens. 1998, 64, 1107-1113.

17. Tatsumi, K.; Yamashiki, Y.; Canales, T.; Taipe, C.L.R. Crop classification of upland fields using random forest of time-series Landsat 7 ETM+ data. Comput. Electron. Agric. 2015, 115, 171-179. [CrossRef]

18. Inglada, J.; Arias, M.; Tardy, B.; Hagolle, O.; Valero, S.; Morin, D.; Dedieu, G.; Sepulcre, G.; Bontemps, S.; Defourny, P.; et al. Assessment of an operational system for crop type map production using high temporal and spatial resolution satellite optical imagery. Remote Sens. 2015, 7, 12356-12379. [CrossRef]

19. Rizzi, R.; Rudorff, B.F.T. Estimativa da área de soja no Rio Grande do Sul por meio de imagens Landsat. Rev. Bras. Cartogr. 2005, 57, 226-234.

20. Badhwar, G.D. Classification of corn and soybeans using multitemporal thematic mapper data. Remote Sens. Environ. 1984, 16, 175-181. [CrossRef]

21. Schultz, B.; Immitzer, M.; Formaggio, A.R.; Sanches, I.D.A.; Luiz, A.J.B.; Atzberger, C. Self-guided segmentation and classification of multi-temporal Landsat 8 images for crop type mapping in southeastern Brazil. Remote Sens. 2015, 7, 14482-14508. [CrossRef]

22. Vieira, M.A.; Formaggio, A.R.; Rennó, C.D.; Atzberger, C.; Aguiar, D.A.; Mello, M.P. Object based image analysis and data mining applied to a remotely sensed Landsat time-series to map sugarcane over large areas. Remote Sens. Environ. 2012, 123, 553-562. [CrossRef]

23. Rudorff, B.F.T.; Aguiar, D.A.; Silva, W.F.; Sugawara, L.M.; Adami, M.; Moreira, M.A. Studies on the rapid expansion of sugarcane for ethanol production in São Paulo State (Brazil) using Landsat data. Remote Sens. 2010, 2, 1057-1076. [CrossRef]

24. Sanches, I.D.; Epiphanio, J.C.N.; Formaggio, A.R. Culturas agrícolas em imagens multitemporais do satélite Landsat. Agric. São Paulo 2005, 52, 83-96.

25. Brown, J.C.; Kastens, J.H.; Coutinho, A.C.; de Castro Victoria, D.; Bishop, C.R. Classifying multiyear agricultural land use data from Mato Grosso using time-series MODIS vegetation index data. Remote Sens. Environ. 2013, 130, 39-50. [CrossRef]

26. MacDonald, R.; Hall, F.; Erb, R. The use of Landsat data in a large area crop inventory experiment (LACIE). In Proceedings of the LARS Symposia, Sioux Falls, SD, USA, 25-29 October 1975.

27. Atzberger, C. Advances in remote sensing of agriculture: Context description, existing operational monitoring systems and major information needs. Remote Sens. 2013, 5, 949-981. [CrossRef] 
28. Rembold, F.; Atzberger, C.; Savin, I.; Rojas, O. Using low resolution satellite imagery for yield prediction and yield anomaly detection. Remote Sens. 2013, 5, 1704-1733. [CrossRef]

29. Kovalskyy, V.; Roy, D.P. The global availability of Landsat 5 TM and Landsat 7 ETM+ land surface observations and implications for global $30 \mathrm{~m}$ Landsat data product generation. Remote Sens. Environ. 2013, 130, 280-293. [CrossRef]

30. Whitcraft, A.K.; Becker-Reshef, I.; Killough, B.D.; Justice, C.O. Meeting earth observation requirements for global agricultural monitoring: An evaluation of the revisit capabilities of current and planned moderate resolution optical earth observing missions. Remote Sens. 2015, 7, 1482-1503. [CrossRef]

31. Loveland, T.R.; Dwyer, J.L. Landsat: Building a strong future. Remote Sens. Environ. 2012, 122, $22-29$. [CrossRef]

32. Fehr, W.R.; Caviness, C.E. Stages of Soybean Development; Special Report 80; Iowa State University: Ames, Iowa, USA, 1977.

33. Asner, G.P. Cloud cover in Landsat observations of the Brazilian Amazon. Int. J. Remote Sens. 2001, 22, 3855-3862. [CrossRef]

34. Sugawara, L.M.; Rudorff, B.F.T.; Adami, M. Viabilidade de uso de imagens do Landsat em mapeamento de área cultivada com soja no Estado do Paraná. Pesqui. Agropecu. Bras. 2008, 43, 1763-1768. [CrossRef]

35. Luiz, A.J.B.; Formaggio, A.R.; Epiphanio, J.C.N.; Arenas-Toledo, J.M.; Goltz, E.; Brandão, D. Estimativa amostral objetiva de área plantada regional, apoiada em imagens de sensoriamento remoto. Pesqui. Agropecu. Bras. 2012, 47, 1279-1287. [CrossRef]

36. Gallego, F.J. Crop area estimation in the MARS project. In Proceedings of the Conference on Ten Years of the MARS Project, Brussels, Belgium, 22-23 April 1999.

37. Gallego, J.; Bamps, C. Using CORINE land cover and the point survey LUCAS for area estimation. Int. J. Appl. Earth Obs. Geoinformation 2008, 10, 467-475. [CrossRef]

38. Kleweno, D.D.; Miller, C.E. 1980 AgRISTARS DC/LC Project Summary: Crop Area Estimates for Kansas and Iowa; US Department of Agriculture, Economics and Statistics Service: Washington, DC, USA, 1981.

39. Stehman, S.V.; Sohl, T.L.; Loveland, T.R. Statistical sampling to characterize recent United States land-cover change. Remote Sens. Environ. 2003, 86, 517-529. [CrossRef]

40. Whitcraft, A.K.; Vermote, E.F.; Becker-Reshef, I.; Justice, C.O. Cloud cover throughout the agricultural growing season: Impacts on passive optical earth observations. Remote Sens. Environ. 2015, 156, 438-447. [CrossRef]

41. Wilson, A.M.; Parmentier, B.; Jetz, W. Systematic land cover bias in Collection 5 MODIS cloud mask and derived products-A global overview. Remote Sens. Environ. 2014, 141, 149-154. [CrossRef]

42. Ackerman, S.A.; Frey, R.; Strabala, K.; Liu, Y.; Gumley, L.; Baum, B.; Menzel, P. Discriminating Clear-Sky from Cloud with MODIS Algorithm Theoretical Basis Document (MOD35) V6.1; Cooperative Institute for Meteorological Satellite Studies, University of Wisconsin-Madison: Madison, WI, USA, 2010.

43. Ackerman, S.A.; Holz, R.E.; Frey, R.; Eloranta, E.W.; Maddux, B.C.; McGill, M. Cloud detection with MODIS. Part II: Validation. J. Atmos. Oceanic Technol. 2008, 25, 1073-1086. [CrossRef]

44. King, M.D.; Platnick, S.; Menzel, W.P.; Ackerman, S.A.; Hubanks, P.A. Spatial and temporal distribution of clouds observed by MODIS onboard the terra and aqua satellites. IEEE Trans. Geosci. Remote Sens. 2013, 51, 3826-3852. [CrossRef]

45. Stengel, M.; Mieruch, S.; Jerg, M.; Karlsson, K.G.; Scheirer, R.; Maddux, B.; Meirink, J.F.; Poulsen, C.; Siddans, R.; Walther, A.; et al. The clouds climate change initiative: Assessment of state-of-the-art cloud property retrieval schemes applied to AVHRR heritage measurements. Remote Sens. Environ. 2015, 162, 363-379. [CrossRef]

46. Stubenrauch, C.J.; Rossow, W.B.; Kinne, S.; Ackerman, S.; Cesana, G.; Chepfer, H.; Di Girolamo, L.; Getzewich, B.; Guignard, A.; Heidinger, A.; et al. Assessment of global cloud datasets from satellites: Project and database initiated by the GEWEX radiation panel. Bull. Am. Meteorol. Soc. 2013, 94, 1031-1049. [CrossRef]

47. The Brazilian Institute of Geography and Statistics (IBGE). Divisão Regional do Brasil em Mesorregiões e Microrregiões e Microrregiões Geográficas; IBGE: Rio de Janeiro, Brazil, 1990.

48. Inman-Bamber, N.G. Sugarcane water stress criteria for irrigation and drying off. Field Crops Res. 2004, 89, 107-122. [CrossRef] 
49. Hagos, H.; Worku, W.; Takele, A. Effect of drying off period and harvest age on quality and yield of ratoon cane (Saccharium officinarium L.). Adv. Crop Sci. Technol. 2014, 2, 1-5.

50. Schultz, B.; Immitzer, M.; Formaggio, A.R.; Atzberger, C. Object-based crop classification using multitemporal OLI imagery and chain classification with random forest. In Proceedings of the XVII SBSR Brazilian Symposium on remote Sensing, João Pessoa-PB, Brasil, 27-29 May 2015; pp. 3059-3066.

51. Land Processes Distributed Active Archive Center (LPDAAC). MODIS Reprojection Tool Swath User Manual Release 2.2; USGS Earth Resources Observation and Science Center (EROS): Sioux Falls, SD, USA, 2010.

52. R Core Team. R: A Language and Environment for Statistical Computing; R Foundation for Statistical Computing: Vienna, Austria, 2014.

53. Matzke, N.J. Modiscloud: An R Package for processing MODIS Level 2 Cloud Mask products. The incidence and implications of clouds for cloud forest plant water relations. Ecol. Lett. 2013, 16, 307-314.

54. Raster: Geographic Data Analysis and Modeling. Available online: http://cran.univ-lyon1.fr/web/ packages/raster/ (accessed on 4 March 2016).

55. Massey, F.J. The Kolmogorov-Smirnov Test for goodness of fit. J. Am. Stat. Assoc. 1951, 46, 68-78. [CrossRef]

56. Fritz, S.; See, L.; McCallum, I.; You, L.; Bun, A.; Moltchanova, E.; Duerauer, M.; Albrecht, F.; Schill, C.; Perger, C.; et al. Mapping global cropland and field size. Glob. Chang. Biol. 2015, 21, 1980-1992. [CrossRef] [PubMed]

57. Sano, E.E.; Ferreira, L.G.; Asner, G.P.; Steinke, E.T. Spatial and temporal probabilities of obtaining cloud-free Landsat images over the Brazilian tropical savanna. Int. J. Remote Sens. 2007, 28, 2739-2752. [CrossRef]

58. The Brazilian Institute of Geography and Statistics (IBGE). Sistema IBGE de Recuperação Automática. Available online: http:/ /www.sidra.ibge.gov.br (accessed on 8 March 2015).

59. Luiz, A.J.B.; Schultz, B.; Trabaquini, K.; Eberhardt, I.D.R.; Formaggio, A.R. Método para estratificação em levantamentos agrícolas com mais de uma variável; Embrapa Meio Ambiente, Embrapa: Jaguariúna, Brazil, 2015.

60. Schultz, B.; Formaggio, A.R.; Eberhardt, I.D.R.; Sanches, I.D.A.; Oliveira, J.C.; Luiz, A.J.B. Classificação orientada a objetos em imagens multitemporias Landsat aplicada na identificação de cana-de-açúcar e soja. Rev. Bras. Cartogr. 2016, in press.

61. Grzegozewski, D.M.; Johann, J.A.; Uribe-Opazo, M.A.; Mercante, E.; Coutinho, A.C. Mapping soya bean and corn crops in the State of Paraná, Brazil, using EVI images from the MODIS sensor. Int. J. Remote Sens. 2016, 37, 1257-1275. [CrossRef]

62. Arvor, D.; Jonathan, M.; Meirelles, M.S.P.; Dubreuil, V.; Durieux, L. Classification of MODIS EVI time series for crop mapping in the state of Mato Grosso, Brazil. Int. J. Remote Sens. 2011, 32, 7847-7871. [CrossRef]

63. Mello, M.P.; Vieira, C.A.O.; Rudorff, B.F.T.; Aplin, P.; Santos, R.D.C.; Aguiar, D.A. STARS: A new method for multitemporal remote sensing. IEEE Trans. Geosci. Remote Sens. 2013, 51, 1897-1913. [CrossRef]

64. Vuolo, F.; Ng, W.T.; Atzberger, C. Innovative approach for smoothing and gap-filling of high resolution multi-spectral time series: Example of Landsat data. Remote Sens. Environ. 2016. under review.

65. Adami, M.; Rizzi, R.; Moreira, M.A.; Rudorff, B.F.T.; Ferreira, C.C. Amostragem probabilística estratificada por pontos para estimar a área cultivada com soja. Pesqui. Agropecu. Bras. 2010, 45, 585-592. [CrossRef]

66. Ban, Y. Synergy of multitemporal ERS-1 SAR and Landsat TM data for classification of agricultural crops. Can. J. Remote Sens. 2003, 29, 518-526. [CrossRef]

67. Larrañaga, A.; Álvarez-Mozos, J.; Albizua, L. Crop classification in rain-fed and irrigated agricultural areas using Landsat TM and ALOS/PALSAR data. Can. J. Remote Sens. 2011, 37, 157-170. [CrossRef]

68. Moran, M.S.; Hymer, D.C.; Qi, J.; Kerr, Y. Comparison of ERS-2 SAR and Landsat TM imagery for monitoring agricultural crop and soil conditions. Remote Sens. Environ. 2002, 79, 243-252. [CrossRef]

(C) 2016 by the authors; licensee MDPI, Basel, Switzerland. This article is an open access article distributed under the terms and conditions of the Creative Commons by Attribution (CC-BY) license (http://creativecommons.org/licenses/by/4.0/). 